\title{
ЭКОЛОГО-ФАУНИСТИЧЕСКАЯ ХАРАКТЕРИСТИКА ЗООПЛАНКТОНА ВОДОТОКОВ НАЦИОНАЛЬНОГО ПАРКА «КРАСНОЯРСКИЕ СТОЛБЫ»
}

\section{ECOLOGICAL AND FAUNISTIC \\ CHARACTERISTICS OF ZOOPLANKTON \\ OF THE KRASNOYARSKIE STOLBY NATIONAL PARK WATER CURRENTS}

L. Lukashina

D. Nikonorova

O. Potyutko

Summary. The article analyzes the data on the seasonal and longterm dynamics of the qualitative and quantitative characteristics of zooplankton in the Mana and Bazaikha streams - washing the Krasnoyarsk Stolby National Park. The authors found 62 species and forms of plankters. The main contribution to the formation of the zooplankton communities abundance in rivers was made by rotifers. The maximum quantitative characteristics of zooplankton were observed in the summer.

Keywords: zooplankton, abundance, trophic structure, Mana River, Bazaikha River.

\author{
Лукашина Людмила Сергеевна \\ Аспирант, Российский Государственный \\ Социальный Университет; м.н.С., Институт \\ глобального климата и экологии, (Москва) \\ lukashina.96@mail.ru \\ Никонорова Дарья Владимировна \\ Аспирант, Российский Государственный \\ Сочиальный Университет, (Москва) \\ Потютко Олег Михайлович \\ К.б.н, в.н.С., Институт глобального климата \\ и экологии, (Москва) \\ Аннотация. В статье проанализированы данные по сезонной и многолет- \\ не динамике качественных и количественных характеристик зооплан- \\ ктона водотоков Мана и Базаиха - омывающих Национальный парк \\ Красноярские Столбы. Авторами встречено 62 вида и формы планктеров. \\ Основной вклад в формирование численности зоопланктонных сооб- \\ ществ рек вносили коловратки. Максимальные количественные характе-
} ристики зоопланктона наблюдались в летний период.

Ключевые слова: зоопланктон, численность, трофическая структура, река Мана, река Базаиха.

относятся к малым водотокам, основными притоками которых до 95\% общего числа формируют кренали и родниковые ручьи [3].

Недостаточная исследованность фаунистического состава исследованных рек, а также его экологических и географических составляющих, явились причинами цели нашего исследования - определить современный состав фауны зоопланктонных сообществ рек Мана и Базаиха, а также выявить тенденции изменения качественного и количественного состава в сезонной и годовой динамике.

\section{Материалы и метолы исслеАования}

Материалом нашей работы послужили пробы зоопланктона, собранные в водотоках омывающих границы Национального парка «Красноярские столбы», как на территории самого парка, так и в его охранной зоне: р.Мана - N55.94172, Е92.47525; р.Базаиха,

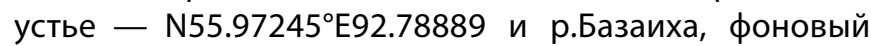

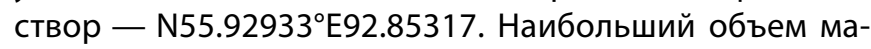
териала пришелся на устьевые области рек Мана и Базаиха. Отбор проб осуществляли с периодичностью раз в месяц с апреля по октябрь. Отбор и обработка 
Таблица 1. Межгодовая динамика численности зоопланктона, экз/м3

\begin{tabular}{|l|l|l|l|l|}
\hline & $\mathbf{2 0 1 8}$ & $\mathbf{2 0 1 9}$ & $\mathbf{2 0 2 0}$ & $\mathbf{2 0 1 8 - 2 0 2 0}$ \\
\hline Базаиха & $87 \pm 25$ & $117 \pm 29$ & $1868 \pm 1584$ & $721 \pm 561$ \\
\hline Мана & $162 \pm 94$ & $440 \pm 228$ & $580 \pm 424$ & $394 \pm 16$ \\
\hline
\end{tabular}

проб проведены по общепринятой методике [5,8]. Таксономические состав зоопланктона идентифицировали по соответствующим определительным ключам $[1,2,4,7,9,10]$.

Среди количественных характеристик определяли численность, а также долю таксономических групп в сообществах.

Общий объем материала доступный для исследования за 3 года составил 63 количественные пробы, из которых 21 проба отобрана в р. Мана и 42 пробы - в р. Базаиха.

\section{Результаты \\ и обсужАение}

В составе зоопланктона р. Мана встречено 28 видов и форм. Наибольшее видовое разнообразие характерно для Rotifera - 13 видов и Copepoda - 9 видов, наименьшее число видов принадлежало Cladocera 6 видов. Среди встреченных групп наибольшим числом видов представлен род Cyclops - 4 вида. В группе Cladocera - Bosmina Daphnia по 2 вида, среди Rotifera: Euchlanis, Keratella - по 2 вида.

В сообществе зоопланктона реки Базаиха встречено 34 вида, среди которых наибольшее видовое разнообразие, так же как и в р. Мана принадлежало Rotifera - 20. Минимальным числом видов Copepoda-9 и, Cladocera - 5 видов. В группе Rotifera наибольшим разнообразием представлены роды: Euchlanis, Keratella, Disstrocha - по 2 вида, род Notholca представлен 3 видами.

По Одуму [6] вид считается обязательным, если его частота встречаемости лежит в диапазоне от 50$100 \%$, второстепенным, когда частоты встречаемости ледат в диапазоне от 25 до 50\% и случайными - от 1 до $25 \%$. В таком случае в р. Мана доминировало 2 вида: Keratella quadrata (Müller, 1786) и Cyclops strenuus Fischer, 1851. Группа второстепенных, чья частота встречаемости лежит в диапазоне от 25 до 50\% насчитывает 6 видов: Bosmina longirostris (O.F. Müller, 1776), B. longispina Leydig, 1860, Keratella cochlearis (Gosse, 1851), Cyclops vicinus Uljan, Diacyclops languidus (G.O.Sars, 1863), Trichotria truncata (Whitelegge, 1889). Оставшиеся 20 видов отнесены к случайным.
Комплекс доминирующих видов по частоте встречаемости в р. Базаиха, так же как и в р. Мана, представлен 2 видами, однако, не смотря на географическую близость исследованных водных объектов, а также схожесть гидрологических и климатических условий, состав доминирующих видов представлен другой группировкой, так основной вклад в формирование численности здесь вносили Rotifera: Euchlanis lyra Hudson, 1886, Scapholeberis mucronata (O.F. Muller, 1776) с частотой встречаемости от 50 до 60\%. Группа второстепенных - Notholca acuminata (Ehrenberg, 1832), Ectocyclops phaleratus (Koch, 1838), Eucyclops macrurus (G.O.Sars, 1863), Chydorus sphaericus (O.F. Muller, 1776) - от 25 до 50\%. Комплекс случайных видов с частотой менее $25 \%$ объединял 28 видов.

В фауне зоопланктона исследованных водотоков преобладали вертикаторы, 43\% встреченных видов, доля первичных фильтраторов составляла - 16\%, хвататели - 14\%, остальные трофические группировки были представлены единичными видами, среди которых собиратели и вторичные фильтраторы представлены по 8\%, хвататели-всасыватели и фильтраторы - 6 и $4 \%$ соответственно.

В реке Мана большая часть видов - $43 \%$ от общего числа представлена эвритопными видами. Литоральная группа включала 32\%. На долю истинно планктонных видов приходилось 21\% фауны, группа фитофильных - представлена 4\%.

В связи с отчетливо выраженной гидродинамической активностью р. Базаиха соотношение жизненных форм зоопланктона имело заметные отличия, так эвритопные и литоральные виды - представлены равными долями и составляли по 38\% общей фауны. Типично планктонные виды составляли лишь - 12\% фауны. В р. Базаиха отмечен ряд жизненных форм, не встречающихся в р. Мана такие как - литорально-бентические (6\%), фитофильно-бентические (3\%) и фитофильные (3\%).

Относительно географического распространения, встреченные нами виды зоопланктона принадлежали ко всесветно распространенные виды - 53\%, палеарктические и голарктические виды представлены равными долями - 24\% и - 22\% соответственно. Максимальное число всесветно распространенных видов характерно для р. Базаиха - (65\%), доля космополитов в р. Мана 
составляла 46\%. Группы палеарктических и голарктических видов в р. Базаиха представлены равны долями по 18\%, в р. Мана — палеаркты 29\%, голаркты $25 \%$.

Из таблицы следует, что среднегодовая численность в исследуемый период возрастает в межгодовой динамике от 2018 к 2020 году, при этом минимальное и максимальное значения характерны для р. Базаиха, амплитуда колебаний численности в р. Мана значительно ниже. Максимальные значения численности в исследуемых реках зарегистрированы летом 2020 г.- река Базаиха 12,48 тыс. экз./М³, река Мана - 3,58 тыс. экз./м³ (таблица 1).

Увеличение численности зоопланктона в реке Базаиха было связано с массовым развитием вертификаторов Euchlanis lyra Hudson, 1886 и первичных фильтраторов Scapholeberis mucronata (O.F. Muller, 1776). В реке Манаразвитием коловраток вертикаторов Keratella quadrata (Muller, 1786) и Keratella cochlearis (Muller, 1786).

Минимальные значения численности зарегистрированы для реки Базаиха осенью 2018 г.- 20 экз./м³, для реки Мана весной того же года - 80 экз./М³(таблица 1).

В 2018-2020 гг. средняя численность зоопланктона за вегетационный период в реке Базаиха была в 2 раза выше, чем в р. Мана.

\section{Зак^ючение}

В период исследований малых водотоков Национального парка «красноярские столбы» в составе зоопланктона встречено в общей сложности 49 видов беспозвоночных, среди которых наибольшее видовое разнообразие принадлежало Rotifera - 25, число видов веслоногих - 13 и ветвистоусых - 11 раков значительно уступало разнообразию коловраток. В количественном отношении основной вклад в развитие сообществ также вносили коловратки на протяжении всего вегетационного периода.

В зоогеографическом отношении зоопланктон сформирован всесветно распространенными видами - достигающими 65\% фауны, им сопутствовали в равных долях палеарктические и голарктические виды - составляя от 24 до 26\%.

Основной структурообразующий комплекс видов зоопланктона для исследуемых рек включал в себя следующие виды: Euchlanis lyra Hudson, 1886, Scapholeberis mucronata (O.F. Muller, 1776) (р. Базаиха), Keratella quadrata (Müller, 1786), Cyclops strenuus Fischer, 1851 (р. Мана).

Количественное развитие зоопланктонных сообществ исследованных водотоков испытывало закономерное увеличение в летний период, достигая максимальных значений к июлю.

\section{БлагоАарности}

Коллектив авторов приносит искреннюю благодарность к.б.н. Т.Н. Ануфриевой за любезно предоставленный материал для этой статьи, а также консультации по гидрологическому и гидрохимическому режиму исследованных рек.

\section{ЛИТЕРАТУРА}

1. Боруцкий Е.В., Степанова Л.А., Кос М.С. Определитель Calanoida пресных вод СССР. Л.: Наука, 1991. 504 С.

2. Жизнь пресных вод СССР / Под ред. В.И. Жадина. Москва: Изд-во Акад. наук СССР, 1940. Т. 1. 460 С.

3. Запекина-Дулькейт Ю.И., Дулькейт Г.Д. Гидробиологическая и ихтиологическая характеристика водоемов государственного заповедника «Столбы» // Труды государственного заповедника «Столбы». Красноярск, 1961. № 3. 110 с.

4. Кутикова Л.А. Коловратки фауны ССС (Rotatoria). Л.: Наука. 1970. 744 с.

5. Методические рекомендации по сбору и обработке материалов при гидробиологических исследованиях на пресноводных водоемах. Зоопланктон и его продукция. Л.: ГосНИОРХ, 1982. 33 с.

6. Одум Ю. Экология / Под ред. В.Е. Соколова. М.: Мир, 1986. Т. 2. 376 с.

7. Определитель зоопланктона и зообентоса пресных вод Европейской России. Т. 1 Зоопланктон / Под ред. В.Р. Алексеева, С.Я. Цалолихина. М.: Товарищество научных изданий КМК, 2010. 456 с.

8. Руководство по гидробиологическому мониторингу пресноводных экосистем / Под ред. В.А. Абакумова. СПб.: Гидрометеоиздат, 1992.318 с.

9. Смирнов Н.Н. Chydoridae фауны мира. Фауна СССР. Ракообразные. Т. 1. Вып. 2. Л.: Наука, 1971. 531 с.

10. Чертопруд М.В., Чертопруд Е.С. Краткий определитель беспозвоночных пресных вод центра Европейской России. Москва: КМК, 2011.219 с.

11. Чужекова Т.А. Структурно-функциональные свойства сообществ макрозообентоса родниковых ручьев бассейна Средней Волги авторефат дисс. ... кандидата биологических наук / Санкт-Петеребург, 2016. 24 с.

12. Allan J., Castillo M. Stream Ecology: Structure and function of running waters. Springer Science \& Business Media, 2007. 444 c.

13. Illies J. Die Besiedlung der Fulda (insb. das Benthos der Salmonidenregion) nach dem jetzigen Stand der Untersuchung // Berichte der Limnol. Flußstation Freudenthal. 1953. V. 5. S. 1-28. 
14. Illies J. Die Lebensgemeinschaft des Bergbaches. Wittenberg Lutherstadt: Ziemsen, 1961. 106 c.

15. Illies V.J. Die Bedeutung der Strömung für die Biozönose in Rhithron und Potamon //1962. V. 213. № 1961. S. 433-435.

16. Minshall G.W. Role of allochthonous detritus in the trophic structure of a woodland springbrook community // Ecology. 1967. V. 48. № 1. S. $139-149$.

17. Vannote R.L., Minshall G.W., Cummins K.W., Sedell J.R. \& Cushing C.E. The River Continuum Concept // Can. J. Fish. Aquat. Sci. 1980. V. 37. № 1. S. $130-137$.

18. Vannote R.L., Sweeney B.W. Larval Feeding and Growth Rate of the Stream Cranefly Tipula abdominalis in Gradients of Temperature and Nutrition // Proc. Acad. Nat. Acad. Nat. Sci. Philadelphia. 1985. V. 137. № 2. S. 119-128.

() Лукашина Людмила Сергеевна ( lukashina.96@mail.ru ),

Никонорова Дарья Владимировна, Потютко Олег Михайлович.

Журнал «Современная наука: актуальные проблемы теории и практики»

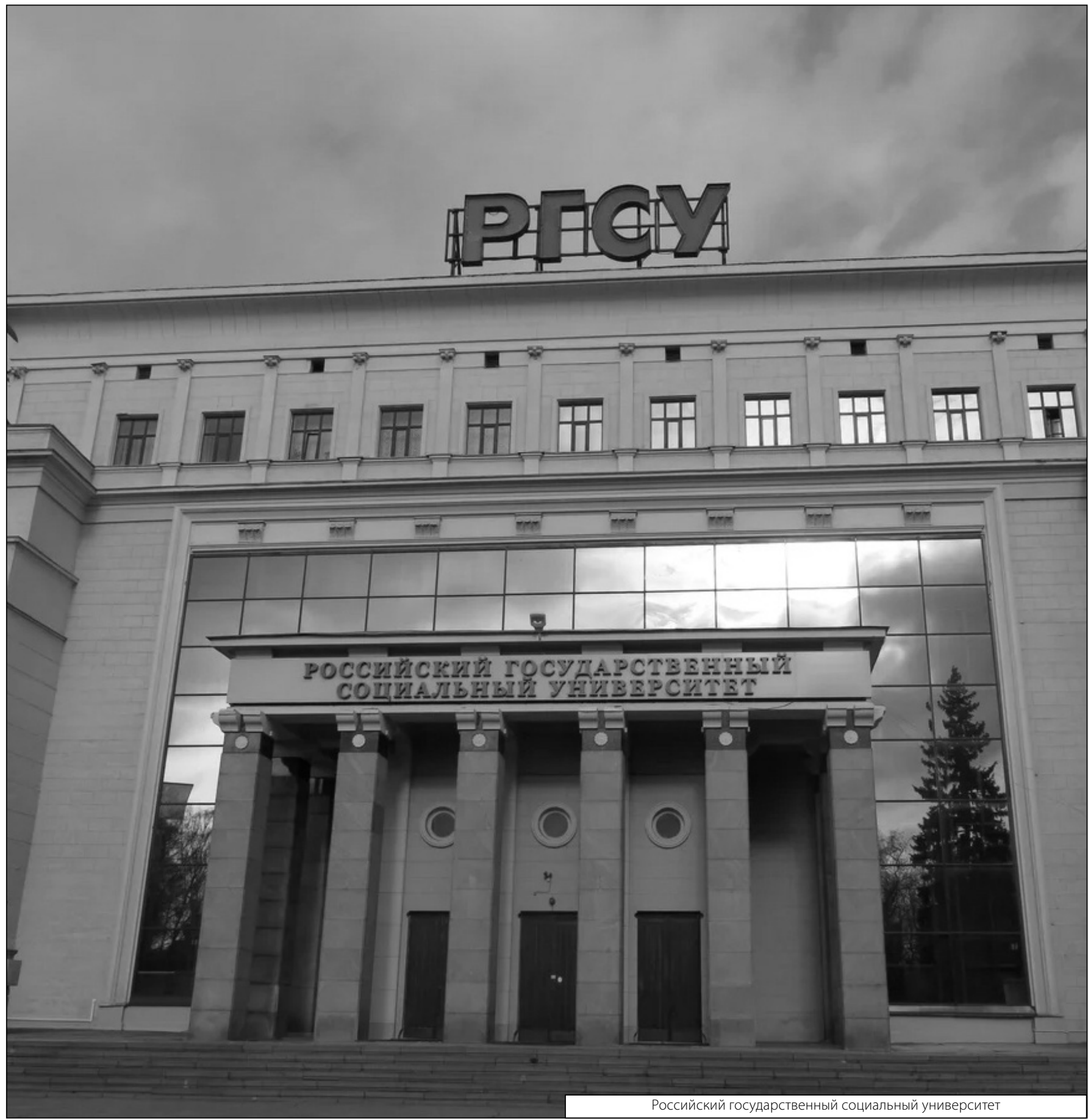

